\title{
Audiences Opinion Research The Role and Function of Public Broadcaster in Indonesia
}

\author{
Fistian Prajayanti
}

\begin{abstract}
The purpose of this research is to find out and describe the opinions of the audience of TVRI Station East Java as one of public broadcasting institutions in Indonesia which is also supporting organizations of the national TVRI, based on Government's Regulation No.11 in 2005 and No. 13 of 2005. It is The Government regulations stipulate that Public Broadcasters must be independent, neutral, not commercial, and serves as the guardian of the public interest. This surely brings out opinions, including the pros and cons that changes votes is simply limited to a change of status and has yet to lead to institutional transformation as the guardian of the public interest is fully due to TVRI for decades was used as propaganda by the state. Therefore, knowing the audience opinion tendency can be known whether TVRI has done in roles and functions as Public Broadcasters or not yet.

This research used descriptive survey method with the technique spread of questionnaires to 100 audiences of TVRI Station East Java in Surabaya. Within framework, analysis of cross-tabulations were used to find out the trend of opinion of an audience that is formed.

The results of this research show that most audience members opined that TVRI Station East Java has been positive toward the roles and functions of the Public Broadcasters. In addition of the result, there are the tendency of viewers opinions based on gender, age, habits are watching, and the duration of the watch shows the significant positive opinion in favor of the changes for Public Broadcasters as TVRI.
\end{abstract}

Keywords-Audience Opinion, Mass Media, Public Broadcasters, Public Opinion.

\section{INTRODUCTION}

$\mathrm{T}_{\text {orga }}^{\mathrm{H}}$ HIS research on developing opinions about an organization or company needs to be done because it is capable of being material evaluation for the existence of an organization or company to adapt in environmental changes. As the old saying goes, there is nothing so constant as change. Indeed, the constancy of change becomes more and more apparent as we move further into this new millenium, and the rate of change seems to increase on a daily basis. [5]. This demanding organization to able to

Fistian Prajayanti is with Communication Department, Social and Politics Faculty, Airlangga University, Surabaya - East Java, Indonesia survive or thrive and even towards the destruction of the environment in the process of organization change. Thus, through the power of public opinion must be faced, understood, and dealt with. It provides the psychological environment in which organizations proper or perish. [1].

Opinion research seeks to answer what people think about a company or organization that is not looking for profit. Opinion research includes imagery research, which is trying to find out how a company known for its good reputation, and what the public think about products, services, prices, personnel and practice. [6].

According to J.. Caroll Bateman in his book "Public Relations for Trade Association" tells us that opinion research is an attempt to measure qualitatively and quantitatively, the attitude of the public towards the trading company, industry or other organizations and for his wisdom, the band's style, his service or production. [2]. Public opinion is an opinion which is a collective that shows what the public is thinking as well as certain shows confidence in perception or some kind of judge on a person, organization, product, or show. [8].

The study is contextualized within a public of TVRI Station East Java which as one of public broadcasting institutions in Indonesia and also as supporting organizations of the national TVRI, based on Government's Regulation No.11 in 2005 and No. 13 of 2005. This surely brings out opinions, including the pros and cons that changes votes is simply limited to a change of status and has yet to lead to institutional transformation as the guardian of the public interest is fully due to TVRI for decades was used as propaganda by the state.

Public is the human groups that gather spontaneously on the condition encountered by a question (issue), different opinions on this issue and trying to resolve the issue, and as a result of the desire to hold a discussion with the search for a way out. The public of this research are the audiences in Surabaya city which aged at least 17 years old and watched the program and event TVRI Station East Java. The purpose of this research is therefore to self-describing the opinions formed from audience TVRI Station East Java related whether as public broadcasting media are already running their role and function as Public Broadcasters which must be independent, neutral, not commercial, and serves as the guardian of the public interest. 


\section{II.LITERATURE REVIEW}

Research on public opinion aims to find out what is thought of by the public of a company or organization, why the public thinks so, and how the description and the company's image in the minds of the public, how the reputation of the company, and what the public think about products, services, pricing, advertising, human resources, and practice, as well as what the public likes and doesn't like about the company. [6].

"Opinion" can be related to perceptions and attitude. Perception is an internal process that allows us to select, organize, and interpret stimuli from our environment [7]. Perceptions that arise from any individual publicly will form a particular opinion. Opinion is an open answer (overt) against an issue, or the answers are revealed based on words that are filed in writing or orally. Attitude is the reaction of someone who may be open or visible, but not always intended to be declared or disclosed, because it stated that the attitude is a reaction that is closed (covert). [9]. Opinions that emerged from a public opinion which can be later has a positive, neutral, or negative, and able to provide information for these specific organizations or to be able to perform activities or even not at all.

Public opinion can be considered aa a response or an effect that arises and is given by the public about an issue through the theory of S-O-R (Stimulus Response Organism Theory) which consists of messages (Stimulus-O), public (Organism$\mathrm{O}$ ), effects (Response-O). S-O-R Theory associated with a change in attitude, then there are three important variables i.e. attention, understanding, and acceptance. (Hovland, et al, 1953). [4], [2].

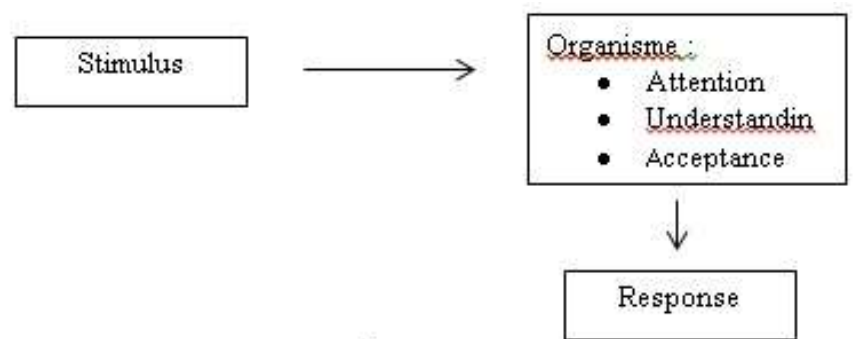

Figure.l. S-O-R Theory

Source: (Effendy, 1993:225)

\section{Methodology}

The research was conducted in Surabaya for knowing of audience's opinion about the role and function of TVRI Station East Java as a public broadcaster. This research used descriptive survey method with the technique spread of questionnaires to 100 audiences of TVRI Station East Java in Surabaya. Measurement of the validity of the instrument indicates that the value of $\mathrm{R}$ Table can be known are 0463 $(1 \%)$ and $0361(5 \%)$. The content validity is established which confirms the audience's opinions about the role and function of public broadcaster included in the questionnaire are adequate which means on top of the $\mathrm{R}$ Table value. The reliability of the questionnaire is well established and has been consistently high as reported in many other studies in the literature. Wilson and Waltman (1988) reported alpha coefficients ranging from .70 to .93 for the sub-scales [10]. It contains 27 items and respondents indicate on a 5-point Likert scale on the frequency of giving tendency of opinions which are positive, neutral, or negative. The results of the measurements indicate that the entire item is the answer shows a 0.764 numbers mean greater than $\mathrm{R}$ Tables. The subdimensions of public broadcaster include: independent, neutral, not commercial, and serves as the guardian of the public interest. The demography section prompts responses on the respondent's background i.e their gender, age, habits are watching, and the duration of the watching.

\section{RESUlTS AND Discussion}

\subsection{Audience Opinion of TVRI Station East Java as Public Broadcaster Institution}

The sub-dimensions of public broadcaster include: independent, neutral, not commercial, and serves as the guardian of the public interest. Table 1 denotes the range of audiences opinion, frequency and procentace.

TABle 1. Audience Opinion OF TVRI Station EAst JaVA AS Public BROADCASTER INSTITUTION

\begin{tabular}{lllll}
\hline Dimensions & $\begin{array}{l}\text { Positive } \\
(\boldsymbol{\%})\end{array}$ & $\begin{array}{l}\text { Neutral } \\
(\boldsymbol{\%})\end{array}$ & $\begin{array}{l}\text { Negative } \\
(\boldsymbol{\%})\end{array}$ & $\begin{array}{l}\text { Total } \\
(\boldsymbol{\%})\end{array}$ \\
\hline Independent & 51 & 47 & 2 & 100 \\
Neutral & 75 & 25 & 0 & 100 \\
Not commercial & 90 & 10 & 0 & 100 \\
$\begin{array}{l}\text { Serves as the } \\
\text { guardian of the }\end{array}$ & 75 & 25 & 0 & 100 \\
public interest & & & & \\
\hline Source: SPSS 12.0 & & & &
\end{tabular}

The findings generally show that most of the audienced have opined the positive trend and argues that TVRI Station East Java has run its role and its function as a public broadcasting institution in the dimension are not commercial as much as $90 \%$, dimensions neutral and serves as the guardian of the public interest as much as $75 \%$ respectively, and independent dimensions as much as $51 \%$.

TABle 2. Audience OPINION OF TVRI StATION EAst JAVA AS PUBLiC BROADCASTER INSTITUTION

\begin{tabular}{llll}
\hline Opinion & Frequency & \% & Total \\
\hline Positive & 70 & 70 & 70 \\
Neutral & 30 & 30 & 30 \\
Negative & 0 & 0 & 0 \\
Total & 100 & 100 & 100 \\
\hline
\end{tabular}

Source: SPSS 12.0

The results show that the tendency of the audience's opinion of the role and function of the TVRI Station East Java as most of the public broadcasters as much as $70 \%$ opined the positive and neutral opined as much as $30 \%$.

\subsection{Audience Opinion based gender, age, habits of watching, and the duration of the watching to TVRI Station East Java as Public Broadcaster Institution.}

\subsubsection{The tendency of Audience Opinion based on Gender.}


TABLE 3. THE TENDENCY OF AUDIENCE OPINION BASED ON GENDER.

\begin{tabular}{llll}
\hline Opinion & $\begin{array}{l}\text { Men } \\
(\mathbf{n = 6 8})\end{array}$ & $\begin{array}{l}\text { Women } \\
(\mathbf{n = 3 2})\end{array}$ & Total \\
\hline Positive & 47 & 23 & 70 \\
Neutral & 21 & 9 & 30 \\
Negative & 0 & 0 & 0 \\
Total & 68 & 32 & 100 \\
\hline Source: SPSS 12.0 & & &
\end{tabular}

Table 3 shows that comparison of frequency values indicates that men are scoring high on positive opinion compared to men.

\subsubsection{The tendency of Audience Opinion based on Age.}

TABLE 4. THE TENDENCY OF AUDIENCE OPINION BASED ON AGE.

\begin{tabular}{lllll}
\hline Opinion & $\begin{array}{l}\mathbf{1 7 - 2 1} \text { years } \\
\text { old }\end{array}$ & $\begin{array}{l}\mathbf{> 2 1 - 4 0} \text { years } \\
\text { old }\end{array}$ & $\begin{array}{l}\mathbf{> 4 0 - 6 0} \\
\text { years old }\end{array}$ & Total \\
\hline Positive & 20 & 7 & 43 & 70 \\
Neutral & 14 & 4 & 12 & 30 \\
Negative & 0 & 0 & 0 & 0 \\
Total & 34 & 11 & 55 & 100 \\
\hline
\end{tabular}

Source: SPSS 12.0

The results show that the audiences within $>40-60$ years old are the most beropini positive sebanyak 43 penonton compared to other ages.

\subsubsection{The tendency of Audience Opinion based on Habits of Watching.}

TABLE 5. THE TENDENCY OF AUDIENCE OPINION BASED ON HABITS OF WATCHING.

4.1 .

\begin{tabular}{ccccc}
\hline Opinion & $\begin{array}{c}\text { Low } \\
\mathbf{( 1 - 2} \\
\text { times in a } \\
\text { weeks) }\end{array}$ & $\begin{array}{c}\text { Medium } \\
\mathbf{( 3 - 4} \text { times } \\
\text { in a weeks) }\end{array}$ & $\begin{array}{c}\text { High } \\
\mathbf{( 5 - 7} \\
\text { times in a } \\
\text { weeks })\end{array}$ & Total \\
\hline Positive & 23 & 11 & 36 & 70 \\
Neutral & 15 & 5 & 10 & 30 \\
Negative & 0 & 0 & 0 & 0 \\
Total & 38 & 16 & 46 & 100 \\
\hline
\end{tabular}

Source: SPSS 12.0

Table 5 shows that respondents with high habit of watching programs of TVRI Station East Java have positive opinion as much as 36 audiences. The audience with the habit of watching low still have a positive opinion of the role and function of the TVRI Station East Java as the Public Broadcasters as much as 23 audiences. Same is the case with 11 of the audience with a medium habit of watching are also positive opined.

\subsubsection{The tendency of Audience Opinion based on The Duration of The Watching.}

TABLE 6. THE TENDENCY OF AUDIENCE OPINION BASED ON THE DURATION OF

\begin{tabular}{ccccc}
\hline Opinion & $\begin{array}{r}\text { Low } \\
\mathbf{( 1 - 3 0}\end{array}$ & $\begin{array}{r}\text { Medium } \\
\mathbf{( 3 1 - 6 0} \\
\text { minutes) }\end{array}$ & $\begin{array}{r}\text { High } \\
\mathbf{( 6 1 - 9 0} \\
\text { minutes) }\end{array}$ & Total \\
\hline Positive & 5 & 30 & 35 & 70 \\
Neutral & 3 & 15 & 12 & 30 \\
Negative & 0 & 0 & 0 & 0 \\
Total & 8 & 45 & 47 & 100 \\
\hline
\end{tabular}

Source: SPSS 12.0
Table 6 shows that respondents with high duration of watching programs of TVRI Station East Java have positive opinion as much as 35 audiences. The audience with the duration of watching low positive opinion has of the role and function of the TVRI Station East Java as the Public Broadcasters as much as 5 audiences. Same is the case with 30 audience with medium habit watch are also positive opined.

\section{DISCUSSION}

The present study was designed to describe the audiences of well-formed opinion about TVRI Station East Java as Public Broadcasters. The findings generally indicate that the audiences have positive opinions about the changing status of TVRI Station East Java which is no longer as the propaganda tools by state media into public broadcaster which is rated by the public institution has run its role and function as a public broadcasting institution. This research shows that TVRI Station East Java is still watched by the audiences as the media information in serving the interests of the public. Thus, it is becoming an evaluation for TVRI Station East Java always to improve the quality of broadcast programs and shows as well as institutional TVRI Station East Java so having a quality competitiveness with other national electronic media.

Investigating the gender differences highlighted that women with the most positive opinion have better interpersonal communication as compared to men.

A majority of the audiences seem to have a high level of positive acceptance to the programs which has been broadcasting until now. It indicates from the audiences with high duration and habits of watching the programs become a loyal audiences of TVRI Station East Java.

\section{CONCLUSION}

The results of this research show that most audience members opined that TVRI Station East Java has been positive toward the roles and functions of the Public Broadcasters. In addition of the result, there are the tendency of viewers opinions based on gender, age, habits are watching, and the duration of the watch shows the significant positive opinion in favor of the changes for Public Broadcasters as TVRI.

\section{REFERENCES}

[1] Cutlip Scott M., et al,. 2006. Effective Public Relations Nineth Edition. Kencana Prenada Media Group. Jakarta.

[2] Effendy, Onong Uchjana. 1993. Ilmu, Teori \& Filsafat Komunikasi. PT. Citra Aditya Bakti: Bandung.

[3] Effendy, Onong Uchjana. 2002. Hubungan Masyarakat Suatu Studi Komunikologis. PT. Remaja Rosdakarya: Bandung.

[4] Hovland, et al, 1953. Communication and Persuasion. Celebrity Endosers: Britain UK.

[5] Miller, K. 2012. Organizational Communication: Approaches and Processes. Thomson Wordsworth: USA.

[6] Moore, H. Frazier. 1988. Hubungan Masyarakat.. Remaja Rosdakarya: Bandung

[7] Mulyana, Deddy. 2004. Ilmu Komunikasi: Suatu Pengantar, PT. Remaja Rosdakarya: Bandung. 
International Conference On Literature, English, Religious And Interdisciplinary Studies (LERIS-2017) Jan. 31-Feb. 1, 2017 Bali (Indonesia)

[8] Newsom, Doug, Judy Vanslyke Turk, and Kruckeberg. 2000. This is PR: The Realities of Public Relations. 7th Edition. Wadsworth Publishing Company: Belmont, California.

[9] Soenarjo, Djoenasih. 1997. Opini Publik. Liberty: Yogyakarta.

[10] Wilson, S. R., \& Waltman, M. 1988. Assessing the Putnam-Wilson Organizational Communication Conflict Instrument. Management Communication Quarterly, 1, 367-388.

https://doi.org/10.1177/0893318988001003006 